\title{
Institutional Formation and Development of the Luhansk Eparchy of the Ukrainian Orthodox Autocephalous Synodal Church (1922-1936)
}

\author{
Mykola Ruban $^{1}$ \\ ${ }^{1}$ Volodymyr Dahl East Ukrainian National University, Severodonetsk, Ukraine \\ Correspondence: Mykola Ruban, Volodymyr Dahl East Ukrainian National University, 59-a Tsentralnyi Avenue, \\ Severodonetsk. 93400, Ukraine. Tel: 38(099)-444-25-54. E-mail: nikolas.kindle@gmail.com
}

Received: May 30, 2021; Accepted: June 16, 2021; Published: June 18, 2021

\begin{abstract}
The article attempts to recreate the process of organizational development of the Luhansk eparchy of the Ukrainian Orthodox Autocephalous Synodal Church of 1922-1936. It was found out that due to the conditions of aggravation of confessional division the representatives of the renewal movement managed to minimize their reformation provisions during 1926-1928. The Synodal Church managed to stabilize the institutional crisis. With the appointment of Bishop Veniamin to a vacant for a long time throne, with the active support of local authorities, the Luhansk diocese has reached its greatest development, covering in its structure about a quarter of the Orthodox communities of the district. It is determined that since the Ukrainian-centric ideological principles of the Synodal Church were not fully embodied in the practical activities of the renewal clergy, the emergence of the Conciliar Episcopal Church as a relatively canonical alternative Reformation denomination of Ukrainian Orthodoxy became relevant in Ukraine. In particular, in the Luhansk region, as a result of the unconstructive methods of Bishop's Photius (Topiro) governing, it was the local diocese of the UCEC that became a refuge for the renewal communities, almost doubling the number of its own parishes during 1928-1929. It is proved that the development of the Synodal Church in the Luhansk region was marked by the lack of an effective system of government, the low discipline of the clergy, and especially given the change in state policy in the field of religion. The historical circumstances of the confessional division of Ukrainian Orthodoxy in the interwar period on the example of a separate region are highlighted. Further research on this topic requires clarification of a number of ethnocultural, political, linguistic, and canonical issues of local renewal communities, which will expand the understanding of the religious worldview of the local population and propose new conceptual approaches to overcoming church divisions.
\end{abstract}

Keywords: Ukrainian Orthodoxy, renewal movement, Ukrainian Orthodox Autocephalous Synodal Church, Donetsk province, Donetsk diocese, Luhansk district, Luhansk diocese

\section{Introduction}

Historical events surrounding the organizational development of the renewal movement in the Orthodox Church in the Donbas are among the least covered pages of domestic religious historiography. As a result of active repressive anti-religious measures, multi-confessionalism in Ukraine, caused by the unresolved issues of church life, was forcibly eliminated - church division on similar grounds was restored in the context of the liberalization of state religious policy in the late 1980s. During 1920s Luhansk was one of the key centers of the renewal movement in the Donbas, and in the early 1990s - the boundary center of the revival of Ukrainian Orthodoxy. The urgency of studying the historical experience of organizational formation of Reformation Orthodox denominations in Donbas, circumstances and personalities of this process becomes extremely important in the context of defining new conceptual approaches to the development of the local Orthodox Church in a specific industrial region of the Ukrainian-Russian border.

The history of the renewal movement in Ukraine, and especially the problem of regulation of state-church relations in the 1920s and 1930s, are presented in the works of G. Bilan (Bilan, 2005), O. Boyko (Boyko, 2003), S. Zhilyuk (Zhilyuk, 2002), O. Ignatusha (Ignatusha, 2004), A. Kiridon (Pashchenko \& Kiridon, 2004), V. Pashchenko (Pashchenko, 1993), O. Trygub (Trigub, 2009), etc. Among the foreign historiography of the Renewal movement, the monographs of B. Bociurkiw (Bociurkiw, 1979/1980), F. Heyer (Heyer, 1953) occupy a prominent place, as well as Russian researchers: A. Krasnov-Levitin (Levitin \& Shavrov, 1996), L. Regelson (Regelson, 2007), Metropolitan Theodosius (Protsyuk) (Theodosius (Protsyuk), 2004), Metropolitan Ioan (Snichov), Ioan (Snychev), 1993; 2013), M. Shkarovsky (Shkarovsky, 1999), Archpriest V. Lavrinov (Lavrinov, 2017) and the priest I. 
Solovyov (Solovyov, 2002). The first fundamental attempts to study the history of Orthodox denominations in the Donbas in the interwar period are the works of Luhansk lawyer-religious scholar O. Forostyuk (Forostyuk, 2000). Further development of this topic is developed in the studies of I. Dovzhuk (Dovzhuk, 2012), V. Nikolsky (Nikolsky, 2013), V. Pidgayko (Pidgayko, 2020), as well as the author of this investigation (Ruban, 2019; 2020). However, despite the wide factual material available, the historiography of the renewal movement in Donbas is marked by tendencies of confessional perception, has certain inaccuracies, the elimination of which requires the involvement of new sources in the scientific circulation.

Thus, the subject of the proposed study is the activity of the Donetsk (later Luhansk) eparchy of the Renewal Ukrainian Synodal Church, and its chronological boundaries cover the period from the institutional separation of the Renewal movement in March 1922 to the de facto abolition of the Luhansk (Voroshilovgrad) eparchial administration in 1936. The territorial boundaries of the study cover the borders of Luhansk parish, and since 1923 - the province of the same name.

The purpose of the article is to reproduce a holistic picture of the organizational development of the Luhansk diocese of the Renewal Ukrainian Orthodox Autocephalous Synodal Church of 1922 - 1936 on the basis of a comprehensive analysis of historical sources and scientific literature, which provides for the following tasks: first, to explore the preconditions for the institutionalization of the renewal movement in the Luhansk region; secondly, to determine the circumstances and factors of organizational development of the denomination; third, to find out the causes of the defeat of the church reformation in Donbas.

\section{Method}

The methodology of the research is based on the principles of historicism, systematicity, scientificity, verification, the author's objectivity; as well as the use of general scientific and special historical methods (Fullerton, 2011). This metodology provided a detailed analysis of the historical circumstances of the institutional formation and development of the Luhansk eparchy of the Ukrainian Orthodox Autocephalous Synodal Church (1922 - 1936) in a clear chronological sequence.

\section{Results and Discussion}

In the spring of 1922, a rapid revolutionary attempt by members of the Renewal Movement to seize supreme ecclesiastical authority in the Moscow Patriarchate with the participation of Soviet secret services quickly spread to the leading provincial centers, however, in the territory of the workers' provincial Donbas the institutional formation of this movement was carried out very slowly. In June 1922, a temporary renewal diocesan administration was formed in Katerynoslav. Trying to find an understanding with the hierarchs of the Katerynoslav diocese, representatives of the local committee of the «Living Church» invited Archbishop Agapit (Vyshnevsky) of Katerynoslav and its vicars to participate in the work of the committee, in particular, Bishop Ioanikiy (Sokolovsky) of Bakhmut and Bishop Andriy (Odintsov) of Mariupol (Boyko, 2003, p. 45). However, the hierarchs not only responded with a categorical refusal but also began active anti-renewal agitation. On August 23 - 24, 1922, a county congress of clergy and laity was held in Bakhmut to discuss the «Living Church» group. At the opening of the congress, Bishop Ioanikiy (Sokolovsky) made a thorough report in which he severely denounced the figures of the Renewal Movement and called on the local clergy to unite (State Archives of Donetsk Region. F.R-1146. In. 2. C. 109. L. 304 - 305). Archbishop Agapit and his vicars, including Bishops Ioanikiy and Andriy (Odintsov), were soon arrested on what was then a standard charge of opposing the confiscation of church valuables, but after a preliminary investigation and recognition of the «Living Church» program, they were released under an amnesty. On September 4, 1922, by order of the HCA, Archbishop Agapit was appointed temporary head of the Renewal Katerynoslav Diocese (Lavrinov, 2017, p. 39). In early November 1922, on the denunciation of one of the monks and the subsequent discovery of the hidden treasures of the bishop's treasury, Archbishop Agapit and Bishop Ioanikiy were arrested again (State Archives of Dnipropetrovsk Region. F.P-1. In. 1. C. 635. L. 177).

\section{Prerequisites for the Institutionalization of the Renewal Movement in the Luhansk Region}

At the end of December 1922, a congress of the local committee of the «Living Church» group was held in Bakhmut, at which it was decided to recognize the HCA and «create departments on the ground» (Fight of the «living» with the bazaar, 1923). The building of the provincial church administration was sealed, the leadership of which refused to hand over the affairs to the representatives of the «Living Church». On February 14, 1923, at a meeting of the All-Ukrainian Renewal Congress in Kyiv, a body of the highest ecclesiastical authority within Ukraine, Crimea and Galicia - the All-Ukrainian Higher Church Administration (hereinafter - AUHCA) was formed, and on February 16 the First All-Ukrainian Congress of the «Living Church» group took place (Central State Archive of the highest authorities and administration of Ukraine. F. 5. In. 1. C. 2189. L. 224 - 225). On April 12, 1923, the Donetsk Provincial Congress of the «Living Church», took place in Bakhmut where M. Gilyarovsky 
was elected the first head of the newly formed Donetsk diocese. (Central State Archive of the highest authorities and administration of Ukraine. F. 3984. In. 1. C. 355. L. 17). However, at the end of April 1923, the former vicar bishop of Mariupol, Andriy (Odintsov), who had been recruited to the rank of archbishop with the title of Bakhmut and Donetsk, was elected head of the Donetsk diocesan administration. He was recruited by the SPD during his arrest. (Central State Archive of Public Associations of Ukraine. F. 1. In. 20. C. 1772. L. 121.; Lavrynov, 2017, p. 110).

One of the first committees of the «Living Church» in the Donetsk province was founded on February 27, 1923, at the local congress of benefactors in Stanychno-Luhansk volost of Luhansk parish (Forostyuk, 2000, p. 77). Priest Joakim Oleksyuk became the group's representative in Luhansk parish, and the cathedral became St. Nicholas Cathedral in Luhansk (Pidgayko, 2020, p. 535). The brotherhood of the Trinity Monastery (Luhansk) joined the renewal movement, in the spring of 1919, its board submitted an application to the Luhansk Council of Workers' Deputies, informing it of the election of its own council, fraught with revolutionary spirit, and requesting that their brotherhood be officially recognized, calling it a "spiritual labor commune» (Luhansk, 1919). In particular, there is information that one of the former inhabitants, the renewed hieromonk Melchizedek (Filimonov), later moved to the local Greek Catholic community. However, on June 5, 1923, the labor community of the Luhansk monastery was abolished on the basis of a resolution of the presidium of the Luhansk district executive committee of May 21, 1923 (Forostyuk, 2004, p. 50).

On April 29, 1923, the delegation of the Donetsk diocese took part in the work of the renewal All-Russian Council, which officially approved the introduction of a number of reforms of the church system, including the equality of married and unmarried bishops, legalized the second marriage of clergy and introduced a new style calendar. A separate resolution concerned monasteries that were closed and reorganized in the parishes at the labor communes (Lavrinov, 2017, p. 110). On May 3, 1923, the Council adopted the infamous resolution, which was, according to the apt observation of $\mathrm{O}$. Trygub, «perceived with indignation by the majority of the laity and ultimately detrimental to renewal» - deprivation of the dignity and monasticism of Patriarch Tikhon (Trygub, 2009, p. 79). On October $25-27,1923$, a renewal Council of Bishops took place in Kharkiv, at which the formation of the Ukrainian Synodal Church was proclaimed and the resolutions of the All-Russian Council were ratified. The AUHCA was reorganized into the All-Ukrainian Holy Synod, to which Archbishop Andriy Bakhmutsky (Odintsov) was elected (How the All-Ukrainian Holy Synod was formed. 1925; Lavrinov, 2017, p. 110).

During 1923, 40 parishes of the Donetsk diocese were officially registered: 25 in Bakhmut and 15 in Luhansk districts. (Central State Archive of the highest authorities and administration of Ukraine. F. 5. In. 2. C. 1026. L. 11 - 15; Central State Archive of the highest authorities and administration of Ukraine. F. 5. In. 2. C. 968 . L. 19 - 25). There is information that in August 1923 the leadership of the Donetsk diocesan administration made attempts to form a vicar of the Luhansk district church administration, led by the priest V. Sakhnovsky (Forostyuk, 2000, p. 91). Apparently, this is a longtime priest of St. Nicholas Cathedral in Luhansk - Archpriest Ioan Sakhnovsky, who, recognizing the jurisdiction of the Renewed Church in 1922, later took monastic vows, was named Iov and ordained Bishop of Valkivsky - vicar of the Kharkiv Diocese (Lavrynov, 2017, p. 297). This assumption is confirmed by the fact that Archpriest John Sakhnovsky is mentioned in the list of priests of St. Nicholas Church as of 1923 (Sumishin, Korneev, Brel \& Kravchenko, 2011. P. 68). However, according to O. Forostyuk's interesting observation, the security officer was in no hurry to register this body, instead instructed the secret services to «conduct covert surveillance and thus reveal the true physiognomy of both the administration and its employees», and the police not to allow «any religious gatherings» (State Archives of Donetsk Region. F. R-1146. In. 1. C. 279. L. 34).

As a result of active measures of the conservative church opposition in the first half of 1924, the Renewal Church in Ukraine suffered a significant organizational crisis, losing more than 1,000 parishes. After a deep institutional crisis, the development of the Renewal Church in the Luhansk district was significantly slowed down, in particular, the first known parish was registered in the village of Fashchivka only on October 5, 1923 (Forostyuk, 1999, p. 26). As of January 1924, according to S. Zhilyuk, 190 renewal parishes were officially registered in the province (Zhilyuk, 2002, p. 53). Instead, according to official data, as of September 1, 1924, there were 2 registered renewal communities in Luhansk district (State Archives of Chernihiv Region. F.R-17. In. 1. C. 112. L. 461), the total number of renewal communities in the province as of January 1925 decreased to 85 (State Archives of Vinnytsia Region. F.R-197. In. 3. C. 3. L. 157). On November 17, 1924, Archbishop Andriy (Odintsov) headed the Chernihiv Diocese, and on the same day, a congress of the clergy of the Donetsk Diocese took place in Artemivsk, at which Archbishop Oleksandr (Migulin) was elected the new head of the Artemivsk Diocesan Administration (Lavrinov, 2017, p. 110). 


\section{Circumstances and Factors of Organizational Development of the Luhansk Diocese of the Synodal Church}

In 1925 the Synodal Church lost 13 thrones. Instead, only seven new ones were founded. In the spring of 1925, the prospects of the creation of the episcopal vicar department of the Donetsk diocese in Luhansk were outlined. On March 25, 1925, the rector of the church from Kukulovka of the Alexandrian Vicariate, Archpriest Yuriy Prokopovych, was enrolled as a candidate for bishop, on the same day the cleric took monastic vows and was elevated to the rank of Archimandrite (Lavrinov, 2017, p. 209). On April 22, 1925, Archpriest Oleksiy Rozumovsky was appointed Bishop of Luhansk, Vicar of the Donetsk diocese with previous taking monastic vows being named Augustine and elevation to the rank of Archimandrite. Finally, in April 1925, Archimandrite Yuriy (Prokopovych) was ordained Bishop of Luhansk, while Archimandrite Augustyn (Razumovsky) was ordained Bishop of Mariupol, Vicar of the Kterinoslav Diocese (Lavrinov, 2017, p. 36).

On May 14, 1925, a session of the All-Ukrainian Local Council opened in Kharkiv, at which a resolution on the autocephaly of the Ukrainian Church and the rooting of worship services was adopted. The Council was attended by 34 bishops, 88 clergy and 86 laity (Gorain, 1925), including two hierarchs of the Donetsk diocese - Archbishop Alexander Artemivsky (Migulin), Bishop Yuriy of Luhansk (Prokopovich). Among other decisions of the Council was the prohibition of second marriage for the clergy. Thus, at the Second All-Ukrainian Council, Ukrainian reformers managed to minimize excessive reformation tendencies in their internal church practice. On October 7 , 1925, the autocephaly of the Renewal Orthodox Church in Ukraine was confirmed at the Third All-Russian Council (Trygub, 2009, p. 100).

The intensification of church-institutional processes at this time was also facilitated by the new administrative reform of the USSR, as a result of which the provincial division of the republic changed to a district one. Due to the urgent need for effective local governance, there was a need to bring the number of renewal dioceses in line with the new administrative division of the USSR. In accordance with the new reform in June 1925, the Synod of the Synodal Church reorganized the network of diocesan administrations. As a result, 36 dioceses were formed within the respective boundaries of territorial districts (Chronicle. In the Ukrainian Holy Synod, 1925), in particular, the Donetsk diocese was divided into separate Artemivsk and Luhansk. At the beginning of June 1925, Bishop Yuriy (Prokopovych) of Luhansk retired and joined the UAOC, where he was appointed to the Zinoviev throne, and after staying there for a short time, in June 1926 he officially renounced his faith (Three sheets, 1926). On June 3, the newly formed Luhansk Diocesan Administration was headed by the newly appointed Archbishop Pavlo (Maslennikov), transferred from the Katerynoslav Diocese (Lavrinov, 2017, p. 446). As of July 1, 1925, 12 parishes belonged to the Renewal Church in the territory of Luhansk district (Central State Archive of Public Associations of Ukraine. F. 1. In. 20. C. 2007. L. 63), however, none in the district center - Luhansk. On August 5, Archbishop Pavlo (Maslennikov) of Luhansk retired. From August 31, 1925, Archbishop Oleksandr Artemivsky (Migulin) was the temporary head of the Luhansk diocese (Lavrynov, 2017, p. 60).

As the renewal movement was in danger of collapsing due to a significant organizational crisis, a course was taken to curtail reforms, which, however, did not significantly improve its situation, and the Soviet secret services sought mechanisms to control the activities of other Orthodox denominations. On June 4 - 5, 1925, the Lubny Council was held in Ukraine with the participation of 5 hierarchs, at which the Conciliar Episcopal Church, an alternative to the relatively canonical Reformation denomination, was formed.

On September 7, 1925, at a meeting of the All-Ukrainian Synod, the situation in the Luhansk diocese was considered. By the decision of the Synod, Bishop Yuriy (Prokopovych) was finally banned from the clergy, and Bishop Valkivsky - Veniamin was transferred to the vacant Luhansk throne. The temporary composition of the Luhansk eparchial administration was also approved, which included Archpriest M. Yanchenkov, priest D. Klepachevsky, Archdeacon M. Sazonov, and laypeople - S. Chesnokov, V. Onufriev (Zhilyuk, 2002, pp. 189, 191). In September 1925, the Luhansk Administrative Department handed over the St. Nicholas Cathedral to the Luhansk Renewal Community, which numbered about 50 people. The NKVD justified its decision by stating that the synodal group «does not have any church in Luhansk in its use, while the... Old Slavs... have as many as five» (Forostyuk, 2000, p. 77). However, in the autumn of 1925, the struggle for St. Nicholas Cathedral unfolded, and only on November 24, 1925, the community of St. Nicholas Cathedral finally determined its affiliation with the All-Ukrainian Synod (We have: Luhansk, 1926). In February 1926, the community of the majestic Kazan Cathedral of Luhansk voluntarily joined the Renewal Church (Chronicle. In Ukraine: Luhansk, 1926).

Finally, during the first year of Bishop Veniamin 's ministry, the total number of parishes in the Luhansk diocese increased from 12 to 21, and in another year, it reached its maximum - 28, as of May 1, 1927, (Central State Archive of the highest authorities and administration of Ukraine. F. 5. In. 3. C. 1064. L. 4 - 9). In May 1927, the 
All-Ukrainian pre-conciliar meeting took place in Kharkiv. In the same month, Bishop Veniamin of Luhansk retired (Lavrinov, 2017, p. 167). On May 28, 1927, Archimandrite Photius (Topiro) was ordained Bishop of Luhansk (Consecration of the new bishop, 1928). As of January 1, 1928, 165 parishes of the Synodal Church were registered in the Donbas, which were part of 5 dioceses, which accounted for $29.78 \%$ of the total number of Orthodox communities in the region. In particular, the Luhansk Renewal Diocese, having lost one parish, covered 27 communities (Central State Archive of the highest authorities and administration of Ukraine. F. 5. In. 3. C. 116. L. 114 - 119), which was $25.2 \%$ of the total number of Orthodox communities in the region. On May 6 - 14, 1928 , Bishop Photius of Luhansk (Topiro) took part in the work of the local Third All-Ukrainian Council, which determined the key principles of development and course of the All-Ukrainian Synod in the direction of Ukrainianization of services and the establishment of autocephaly.

\section{Analysis of the Causes of the Defeat of the Church Reformation in Donbass}

It should be noted that the catastrophic institutional crisis in the Luhansk diocese was deepened by the scandalous nature and provocative actions of Bishop Photius (Topiro). Under these circumstances, the renewal communities were transferred massively to the jurisdiction of the local bishop of Luhansk UCEC Augustyn (Verbytsky). Only during 1929 did the Donetsk-Luhansk diocese of the UCEC increase the number of parishes in the Luhansk district from 25 to 56 (Trygub, 2009, p. 141). Instead, as of May 3, 1933, out of the 28 parishes of the Luhansk Eparchy of the Synodal Church, only the community of the Kazan Cathedral remained (Forostyuk, 2000, p. 132). Under the pretext of strengthening the last community, the hierarch initiated a meeting and re-election of the parish council, which was a continuation of a deep conflict with its former members, who in September 1933 limited the intervention of Bishop Photius in the financial activities of the parish. As a result, the city administration began to receive numerous mutual complaints in which both parties accused each other of gross violations of religious law. Against this background, the local department of cults initiated an inspection of Bishop Photius for anti-Soviet leanings, and in the autumn of 1933 the hierarch, having effectively led the community to split, was transferred to the Chernihiv diocese and elevated to the rank of archbishop (Forostyuk, 1999, p. 128).

Metropolitan Anatoliy Artemivsky (Sokolov) (Lavrynov, 2017, p. 107) was appointed executive of the Luhansk diocesan administration, while the actual management was carried out by the rector of the Kazan Cathedral, Archpriest Arseniy Gusev (Forostyuk, 1999, p. 129). In June 1935, the Luhansk eparchial administration of the Synodal Church was headed by Bishop Volodymyr Kovin, who, according to O. Forostyuk, «in the conditions of the final destruction of the Synodal Church in Luhansk region only passed resolutions on the dismissal of the clergy» (Forostyuk, 2000, p. ). In the autumn of 1935, in connection with the renaming of the city, the diocese was renamed Voroshilovgrad, and Bishop Volodymyr was transferred to the Chernihiv diocese (Lavrinov, 2017, p. 107). In January 1936, the Voroshilovgrad diocesan administration was headed by Metropolitan Anatoliy (Sokolov), who had been transferred from the abolished Artemivsk diocese, and soon after passed to the Kostroma diocese ((Lavrinov, 2017, p. 107; Pidhaiko, 2020, p. 537), and the Voroshilovgrad district, following the Mariupol and Artemivsk districts, became part of the united Stalin diocese.

\section{Conclusions}

Thus, during the first years of the organizational formation of the renewal movement in the Luhansk region, this process slowed down significantly due to the active anti-renewal opposition of the conservative Moscow Patriarchate and the catastrophic personnel miscalculations of the higher church hierarchy of the newly formed denomination. As the reform movement of Ukrainian Orthodoxy intensified in the context of the escalation of the confessional division of the Ukrainian Orthodox Church, the institutional crisis within the denomination was partially limited. During 1926 - 1928 the Synodal Church managed to stabilize the institutional crisis, although during the period of its greatest development it included only $23.2 \%$ of the registered Orthodox communities of the republic. With the appointment of Bishop Veniamin to a vacant for a long time throne, with the active support of local authorities, the Luhansk diocese has reached its greatest development, covering in its structure about a quarter of the Orthodox communities of the Luhansk district

As the Ukrainian-centric ideological principles were not fully embodied in the practical activities of the Synodal Church, the Council of Bishops was organized in Ukraine as a relatively canonical alternative Reformation denomination of Ukrainian Orthodoxy. In particular, in the Luhansk region, as a result of the unconstructive methods of Bishop's Photius (Topiro) governing, it was the local diocese of the UCEC that became a refuge for the renewal communities, almost doubling the number of its own parishes during 1928-1929. Finally, the development of the Synodal Church in the Luhansk region was marked by the lack of an effective system of government, low discipline of the clergy, and especially given the change in state policy in the field of religion. 


\section{Acknowledgments}

The author of the article expresses his sincere gratitude to the editors of the journal for the advice provided in preparing the article for publication.

\section{References}

Bilan, H. I. (2005) Obnovlenskyi rukh v Ukraini 20 - 30-kh rr. XX st. [The renewal movement in Ukraine in the 20-30s of the twentieth century] (Candidate's thesis). Kyiv. [in Ukrainian].

Bociurkiw, B. (1980). Ukrainization Movements within the Russian Orthodox Church, and the Ukrainian Autocephalous Orthodox Church. Harvard Ukrainian Studies. 1979/1980. Part 1. pp. 92-111. [in English].

Boi «zhyvoi» s bazarom. [Fight «live» with the bazaar]. (1923, January 4). Kommunyst. Kharkov, 2, 3. [in Russian].

Boyko, O. V. (2003). Stanovlennya ta rozvytok obnovlens'koho rukhu na Katerynoslavshchyni v pershiy polovyni 20-kh rokiv XX stolittya. [Formation and development of the renewal movement in the Ekaterinoslav region in the first half of the 1920s]. Hrani. Vol. 6. Dnipropetrovsk. pp. 44 - 52. [in Ukrainian].

Central State Archive of Public Associations of Ukraine. F. 1. In. 20. C. 1772. L. 121.

Central State Archive of Public Associations of Ukraine. F. 1. In. 20. C. 2007. L. 63.

Central State Archive of the highest authorities and administration of Ukraine. F. 5. In. 3. C. 1064. L. 4-9.

Central State Archive of the highest authorities and administration of Ukraine. F. 5. In. 3. C. 116. L. 114-119.

Central State Archive of the highest authorities and administration of Ukraine. F. 3984. In. 1. C. 355. L. 17.

Central State Archive of the highest authorities and administration of Ukraine. F. 5. In. 2. C. 1026. L. 11-15.

Central State Archive of the highest authorities and administration of Ukraine. F. 5. In. 1. C. 2189. L. 224-225.

Central State Archive of the highest authorities and administration of Ukraine. F. 5. In. 2. C. 968. L. 19-25.

Chronicle. In Ukraine: Luhansk. (1926, June 1). Ukrayins'kyy pravoslavnyy blahovisnyk. Kharkiv, 11, 12. [in Russian].

Dovzhuk, I. V. (2012). Rosiys'ka pravoslavna tserkva v kul'turnomu ta ekonomichnomu zhytti Donbasu u 20-kh rr. XX st. [The Russian Orthodox Church in the cultural and economic life of Donbass in the 20s of the twentieth century]. Luhansk: SNU im. Volodymyra Dalya. [in Ukrainian].

Feodosii (Protsiuk), metrop. (2004). Obosoblencheskye dvyzhenyia v pravoslavnoi Tserkvy na Ukrayne (1917-1943). [Separate movements in the Orthodox Church in Ukraine (1917-1943)]. Moscow: Obshchestvo liubytelei tserkovnoi ystoryy. [in Russian].

Forostiuk, O. D. (1999). Pravoslavnaya Luganshchina v gody goneniy i tragicheskikh ispytaniy (1917 - $1988 \mathrm{gg}$.). [Orthodox Luhansk region during the years of persecution and tragic ordeals (1917 - 1988)]. Lugansk: RIO LYVD. [in Russian].

Forostiuk, O. D. (2000). Pravove rehuliuvannia derzhavno-tserkovnykh vidnosyn u radianskii Ukraini v 19171941 rokakh (na materiali Donetskoho rehionu). [Legal regulation of state-church relations in Soviet Ukraine in 1917-1941 (based on the material of the Donetsk region)]. Luhansk: RVV LIVS. [in Ukrainian].

Forostyuk, O. D. (2004). Luhanshchyna relihiyna istorychnyy i pravovyy aspekty. [Luhansk region has historical and legal aspects]. Luhansk: Svitlytsya. [in Ukrainian].

Fullerton, R. (2011). Historical methodology: the perspective of a professionally trained historian turned marketer. Journal of Historical Research in Marketing, 3(4), 436-448. https://doi.org/10.1108/17557501111183608

Gorain, I., prot. (1925, June 1). Otkrytiye Vseukrainskogo Svyashchennogo Sobora. [Opening of the All-Ukrainian Council of Holy]. Golos Pravoslavnoy Ukrainy. 10, 1-2. [in Russian].

Heyer, F. (1953). Die Orthodoxe Kirche in der Ukraine von 1917 bis 1945. Köln-Braunsfeld: Verlagsgesellschaft Rudolf Muller. [in Deutsch].

Ihnatusha, O. M. (2004). Instytutsiynyy rozkol Pravoslavnoyi Tserkvy v Ukrayini: heneza i kharakter XIX st. - 30ti rr. XX st. [Institutional split of the Orthodox Church in Ukraine: genesis and character (XIX century-30s of the XX century)]. Zaporizhzhya: Polihraf. [in Ukrainian].

Ioann (Snychev), mitr. (1993). Tserkovnyye raskoly v Russkoy Tserkvi 20-kh i 30-kh godov XX stoletiya. [Church schisms in the Russian Church in the 1920s and 1930s]. Sortavala. [in Russian].

Ioann (Snychev), mitr. (2013). Stoyaniye v vere: Ocherki tserkovnoy smuty. [Standing in the Faith: Essays on 
Church Troubles]. Moscow: Algoritm. [in Russian].

Kak obrazovalsya Vseukrainskiy Svyashchennyy Sinod. [How the All-Ukrainian Holy Synod was formed]. (1925). Golos Pravoslavnoy Ukrainy. Kharkiv, 1-2, 2-3. [in Russian].

Khirotoniya novago yepiskopa. [Consecration of the new bishop]. (1928, June 1-15). Ukrayins'kyy pravoslavnyy blahovisnyk. Kharkiv, 11-12, 12. [in Russian].

Lavrynov, V. archiepriest. (2017). Obnovlencheskyi raskol v potretakh eho deiatelei. [Renovation split in the portraits of his figures]. Moscow: Obshchestvo liubytelei tserkovnoi ystoryy. [in Russian].

Levitin, A., \& Shavrov, V. (1996). Ocherki po istorii russkoy tserkovnoy smuty. Moscow: Obshchestvo lyubiteley tserkovnoy istorii. [Essays on the History of Russian Church Troubles]. [in Russian].

Lugansk. (1919, March 21). Komunist. Kharkiv, 16(44), 2. [in Russian].

Nikolsky, V. N. (2013) Pravoslavnoye dukhovenstvo Donetchiny, repressirovannoye v 1920-1950 gg. (v dokumentakh i materialakh). [The Orthodox clergy of the Donetsk region, repressed in the 1920s-1950s (in documents and materials)]. Donetsk: Izd-vo DonNU. 194 p. [in Russian].

Pashchenko, V. (1993). Derzhava i pravoslavya v Ukrayini: 20-30 rr. XX st. [State and Orthodoxy in Ukraine: 2030s of the XX century.]. Kyiv. [in Ukrainian].

Pashchenko, V., \& Kyrydon, A. (2004). Bil'shovyts'ka derzhava i pravoslavna tserkva v Ukrayini (1917 - 1930-ti roky). [The Bolshevik State and the Orthodox Church in Ukraine (1917-1930s)]. Poltava. [in Ukrainian].

Pydgayko, V. G. (2020). Luganskaya i Alchevskaya yeparkhiya. [Lugansk and Alchevsk diocese]. Pravoslavnaya entsiklopediya - Orthodox encyclopedia. (Vol. 41). Moscow: Pravoslavnaya entsiklopediya. pp. 530-541. [in Russian].

Regel'son, L. L. (2007). Tragediya Russkoy Tserkvi. [The tragedy of the Russian Church]. Moscow: Izdatel'stvo Krutitskogo podvor'ya, Obshchestvo lyubiteley tserkovnoy istorii. 640 p. [in Russian].

Ruban, M. Y. (2019). Liquidation of the organizational structure of the Renovationist Church in Donbass and persecutions of its clergy in 1929-1937. Bulletin of Luhansk Taras Shevchenko National University. Historical Sciences. Starobilsk. 8(331). pp. 153-164. https://doi.org/10.12958/2227-2844-2019-8(331)-153164. [in English].

Ruban M.Y. (2020). Anti-renovationist opposition in the Orthodox Church in the territory of Donetsk region (1922 - 1925). Visnik of the Volodymyr Dahl East Ukrainian national university: Series «Historical Sciences». Severodonetsk, 3(259). pp. 54-61. https://doi.org/10.33216/1998-7927-2020-259-3-54-61_[in English].

Shkarovskiy, M. V. (1999). Obnovlencheskoye dvizheniye v Russkoy Pravoslavnoy Tserkvi XX veka. [The Renovationist Movement in the Russian Orthodox Church of the $20^{\text {th }}$ century]. Saint-Petersburg: NESTOR. [in Russian].

Solovyov, Y. V. (Ed.). (2002). Obnovlencheskyi raskol (Materyaly dlia tserkovno-ystorycheskoi y kanonycheskoi kharakterystyky). [Renovation schism (Materials for church-historical and canonical characteristics)]. Moscow: Yzd-vo Krutytskoho Patryarsheho Podvoria, Obshchestvo liubytelei tserkovnoi ystoryy. [in Russian].

State Archives of Chernihiv Region. F. R-17. In. 1. C. 112. L. 461.

State Archives of Dnipropetrovsk Region. F. P-1. In. 1. C. 635. L. 177.

State Archives of Donetsk Region. F. R-1146. In. 1. C. 279. L. 34.

State Archives of Donetsk Region. F. R-1146. In. 2. C. 109. L. 304-305.

State Archives of Vinnytsia Region. F. R-197. In. 3. C. 3. L. 157.

Sumishyn, Y. S., Kornyeyev, Y. S., Brel' Y. M., \& Kravchenko, H. M. Luhans'ka yeparkhiya. Informatsiynodovidkove vydannya. [Luhansk diocese. Information and reference publication]. Lugansk: Maksim. [in Russian].

Try lysty. [Three sheets]. (1926, Juni 27). Komunist. Kharkiv, 144 (1929), 3. [in Ukrainian].

Tryhub, O. P. (2009). Rozkol Rosiiskoi Pravoslavnoi Tserkvy v Ukraini (1922-39 rr.): Mizh Derzhavnym Politychnym Upravlinniam ta reformatsiieiu. [The Schism of the Russian Orthodox Church in Ukraine (1922 - 39): Between the State Political Administration and the Reformation]. Monograph. Mykolaiv, 2009. [in Ukrainian]. 
We have: Lugansk. (1926, January 1). Ukrayins'kyy pravoslavnyy blahovisnyk. Kharkiv. 1, 12. [in Russian].

Zhyliuk, S. I. (2002). Obnovlenska Tserkva v Ukraini (1922 - 1928). [Renewal Church in Ukraine (1922-1928)]. Rivne: RDGU. [in Ukrainian].

\section{Copyrights}

Copyright for this article is retained by the author(s), with first publication rights granted to the journal.

This is an open-access article distributed under the terms and conditions of the Creative Commons Attribution license (http://creativecommons.org/licenses/by/4.0/). 